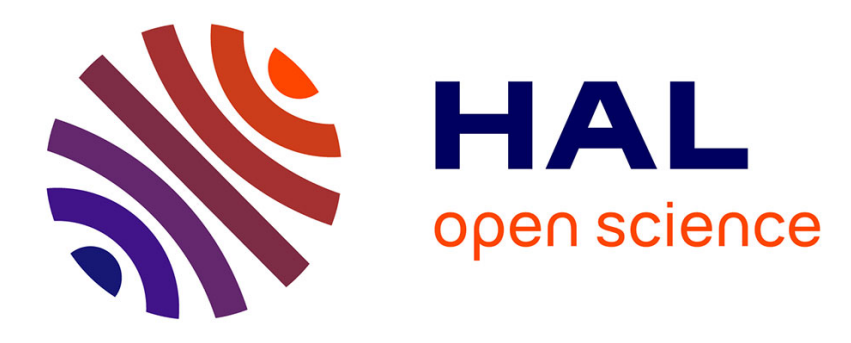

\title{
Review Essay: Some recent publications on the anthropology of Greece and Cyprus
}

\author{
Anne Delouis
}

\section{To cite this version:}

Anne Delouis. Review Essay: Some recent publications on the anthropology of Greece and Cyprus. Journal of the Society for the Anthropology of Europe, 2009, 9 (2), pp.17-20. halshs-00677897

\section{HAL Id: halshs-00677897 https://shs.hal.science/halshs-00677897}

Submitted on 10 Mar 2012

HAL is a multi-disciplinary open access archive for the deposit and dissemination of scientific research documents, whether they are published or not. The documents may come from teaching and research institutions in France or abroad, or from public or private research centers.
L'archive ouverte pluridisciplinaire HAL, est destinée au dépôt et à la diffusion de documents scientifiques de niveau recherche, publiés ou non, émanant des établissements d'enseignement et de recherche français ou étrangers, des laboratoires publics ou privés. 


\section{Review Essay: Some recent publications on the anthropology of Greece and Cyprus}

Iron in the Soul: Displacement, livelihood and health in Cyprus (Studies in Forced Migration, volume 23). Peter Loizos. New York and Oxford: Berghahn Books. 2008. 224pp. ISBN-10: 1845454847.

Blood and Oranges: European Markets and Immigrant Labor in Rural Greece (Dislocations, volume 2). Christopher M. Lawrence. New York and Oxford: Berghahn Books. 2007. 224pp. ISBN-10: 1845453077.

The Nomads of Mykonos: Performing Liminalities in a 'Queer' Space. (New Directions in Anthropology, volume 29). Pola Bousiou. New York and Oxford: Berghahn Books. 2008. 320pp. ISBN-10: 1845454669.

\section{ANNE FRIEDERIKE DELOUIS}

Université d’Orléans

Greece, which one fellow anthropologist once described to me as the "Papua New Guinea of European anthropology,” probably still attracts more ethnographers per head than any other country in Europe. Berghahn Books' recent publication of three monographs on Greek-speaking peoples testifies to this ongoing trend.

For Iron in the Soul: Displacement, livelihood and health in Cyprus, Peter Loizos drew on his long-standing connection with the villagers of Argaki, in the North of Cyprus, among whom he carried out fieldwork first in 1968, then in 1975 after the partition of the island, and again between 2000 and 2004. This long-term study is an in many ways refreshing and optimistic account of the rather successful economic and social integration of Greek Cypriot refugees in the Republic of Cyprus after 1975. Out of a myriad of life stories and ethnographic observations emerges a portrait of resourceful, hard-working people, dedicated to the well-being and advancement of their children, who manage to build up new livelihoods in (at least initially) difficult circumstances. Several factors account for the reconstruction of satisfactory living conditions: the favourable economic situation of 1980s and 1990s Cyprus; thoughtful, carefully calibrated policies devised by the state; but also - 
even if the issue is a sensitive one - the fact that compared to other groups of refugees, Loizos’s informants rather fit the category of “internally displaced persons.” As much disruption as they had to suffer when leaving their homes and most of their belongings without forewarning, they remained close to their relatives, and settled among people who spoke the same language and shared the same religion, in a state that welcomed them unquestioningly as citizens with full rights and some privileges such as free healthcare.

In some ways, Iron in the Soul is a sequel to The Greek Gift (Loizos 1975) and above all to Loizos’s compelling book The Heart Grown Bitter (Loizos 1981), featuring a selection of the same informants more than twenty years on, some of them now exuding the wisdom of old age. With time, the perspective on pre-1975 Argaki has changed somewhat. In tune with the generally optimistic tone of this re-study, Loizos describes this mainly Greek village with a small Turkish minority as a site where a massacre could have taken place in the summer of 1975, but did not. He emphasizes the cordial relations between the two ethnic groups before, and more surprisingly, after the Turkish invasion of Cyprus.

Ostensibly, Iron in the Soul is a study of the impact of refugee status on people's health. But those readers who expect a monograph on this topic alone might be disappointed. Only one chapter deals exclusively with health issues. A comparison between two population samples, one made up of refugees and the other of non-displaced Greek Cypriots, yields a somewhat surprising result. Refugees have suffered slightly more often from heart-related illness, but report less illness overall. Ethnographic evidence makes it plain that the perception of health problems diverges from the real situation: many illnesses and untimely deaths are blamed on the refugee condition. In reality, refugees have benefitted from free health checks and perhaps easier access to preventive medical measures, which might explain their arguably better health status despite the increased workload and deteriorated living 
conditions at least in the first years after 1975. As far as mental health is concerned, Loizos points out individual variation in psychological reactions to displacement and loss.

If one had to label Loizos's work, one might rather opt for the category of political than medical anthropology though. For instance, Loizos offers a fine-tuned and multi-faceted analysis of why a majority of Greek Cypriots, including those of refugee background, voted "no" to the Annan plan in 2004.

Loizos’s recent ethnography also provides material for the understanding of memory, its workings and social functions. In 2003, the border to Northern Cyprus was opened for the first time since 1975. Accounts of former refugees' visits to Argaki suggest that many nourish nostalgic sentiments for the village as it once was, and no longing for its actual rundown state.

Apart from some touching welcoming scenes, the lack of tidiness and cleanliness is stressed again and again. The Turkish inhabitants apparently lack respect not only for cultural heirlooms such as the orthodox village church, but also for some formerly Greek houses in which Turkish families now live, or for the village school used by the Turkish population. The focus on dirt and untidiness is striking and calls for further interpretation.

One would like to know the Turkish take on this, as, in general, one would have liked to read even more about the Turkish Cypriot experience than Loizos’s collaboration with a Turkish sociologist from Argaki has provided. But even so, Loizos’s account makes it clear that despite propaganda efforts to the contrary, the decisive cleavage has always been between Leftists and Nationalists on both sides, probably more than a division on ethnic lines.

Loizos rightly calls the concept of supposedly homogenous "generations” into question, but a series of anecdotes or ethnographic miniatures shows that on the whole the longing for the place, and the sense of what is lost, remains more vivid and painful for those 
who were adults when they had to flee to the South than for their children and grand-children. Perhaps unintentionally, Iron in the Soul leaves a certain impression of closure. In visits to Northern Cyprus, refugees from Argaki could confront their - surely to some extent idealized - memories with the reality of the village, taken over and transformed by Turkish Cypriots. In thirty years, the refugees have built up new livelihoods. The displacement situation does not seem to have taken a dramatic toll on their health. The younger generations look forward and outwards rather than back, and even most of the elder ones oppose a reunification of the island if there are too many strings attached. What remains, bittersweet memories, emotional pain and longing, is perhaps best captured by the phrase “iron in the soul.” Loizos's book includes some photographic portraits and a selection of texts of various types and genres produced by Greek Cypriot refugees themselves.

Like Peter Loizos, Christopher Lawrence has one parent of Greek descent, but unlike the former he did not choose to study in his extended family - which makes perhaps for a more critical stance towards some features of contemporary Greece. Blood and Oranges: European Markets and Immigrant Labour in Rural Greece deals with social and economic relations in farming communities of the Argolida region on the Peleponnesos, a mainly rural area near Nauplio. Lawrence adopts a political-economy perspective to reveal the mechanisms by which modernisation and European integration have brought about a new class of marginalized and sometimes illegal immigrant labourers in rural Greece. While higher gender equality has been achieved and children's rights are better respected than before (children are pampered rather than sent to toil in the fields, and parents invest substantially in their education), rural households now rely on cheap immigrant labor to do the actual agricultural work.

Many of the mostly Albanian labourers achieve legal status when they get working permits for which they pay expensive fees. They enjoy certain social rights (their children are 
educated in Greek state schools, for example), but on the whole their position remains extremely vulnerable as they are excluded from citizenship, often socially ostracized, verbally and physically attacked, and insufficiently protected by the Greek police and the judicial system. Lawrence points out that in what he terms "pluriactive households” many farmers who hire foreign workers actually lead a rentier-style life as mere land-owners, holding civil service positions or running other businesses as entrepreneurs at the same time.

EU subsidies often provide a substantial part of the household income. Lawrence describes the sometimes perverse effects of European economic policies, which may hinder rather than further modernisation, diversification and innovation on the ground, and which cunning farmers and co-operative administrators turn to their (financial) advantage as much as they possibly can.

In this book, which contains eleven photographs and one map of the region, Lawrence is careful to point out local differences between the three villages under study: Agia Triada in the valley, Manesi and Gerbesi higher up in the mountains. The valley is the site of lucrative citrus plantations, while the relatively impoverished mountain villages have to rely on tobacco and vegetable growing as well as shepherding. The further a village is up in the mountains, the more its inhabitants are situated on the left of the political spectrum. Mountain villagers tend to claim descent from Albanian-speaking $14^{\text {th }}$ - and $15^{\text {th }}$-century immigrants (Arvanites), a source of (Greek) ethnic pride.

Christopher Lawrence has crafted a historically grounded, complete ethnography, comprising economic, political, and kinship matters. Religion is the only aspect which is given short shrift (apart from a reference to Orthodox baptism of immigrant children as an attempt to get accepted into the Greek community), probably because it is of little relevance to Lawrence's research questions. The anthropologist is particularly attentive to gender 
issues, such as the sexual exploitation of some female East European immigrants, or their strategy of obtaining protection through marriage with a Greek.

As before with gender inequality, now social inequality between immigrants and Greek citizens is naturalized. That is, many of Lawrence's informants hold the belief that Greeks are a distinct “race” (phili or ratsa), almost genetically predisposed to attaining a higher level of civilization (politismos) than Albanians. The Greek mass media, and private television channels in particular, play an important role here, bolstering Greek nationalism through a certain type of serials and talk-shows, and fostering anti-immigrant sentiment through sensational reports on crimes supposedly or really committed by immigrants. Despite this “neo-racism,” the difference between Greek citizens and immigrants lies in reality more in their respective economic statuses and, above all, consumption practices, than in divergent biological or cultural characteristics, as Lawrence shows. An Albanian immigrant who uses a cell phone, is dressed in a fashionable way and owns a nice car stands a good chance of being accepted as a “Northern Epirote” (i.e., an Albanian-speaking, ethnic Greek) in Argolida.

Globalisation, Lawrence stresses, does not necessarily create more hybrid identities than before. The ethnic and cultural nationalism of Greek farmers is a response to Europeanization rather than a survival of $19^{\text {th }}$-century attitudes.

The third book under review, Pola Bousiou's The Nomads of Mykonos: Performing Liminalities in a 'Queer' Space, is a monograph on a highly unusual topic: a group of people who defy classification and do not consider themselves to form a community, at least most of the time. Bousiou, a Greece-born, LSE-educated anthropologist, carried out fieldwork among the Mykoniots d'élection, a term inspired by Lawrence Durrell (1978). Who are these people, and what justifies lumping them together in a single category?

Bousiou's key informants are Greek individuals who are not originally from the island of Mykonos, but choose to take up residence there for at least part of the year. Their social 
background varies, their economic status remains unclear to the anthropologist. What they do have in common, apart from their attachment to Mykonos, is a certain outlook on life. Mykoniots (not to be confused with Mykonians, the “indigenous” inhabitants of the island) share an interest in Eastern, mostly Indian philosophy and religions, which they mix syncretically with rituals derived from Orthodox Christianity. They have a peculiar aesthetic sensibility, a concern for architecture, particularly the native "cubist” style, the simple but tasteful interior decoration of their homes, or treasured handicraft objects from Greece or India. Many of them take great care over their own apparel, their looks, their bodies, which they display to their peers and tourist “audiences” in everyday or festive "performances." Mykoniots are knowledgeable about local history and traditions which they tend to merge with esoteric beliefs, theorising about energy emanating from the triangle of islands formed by Mykonos, Delos and Tinos or a particular “Delian” light permeating the Mykonos sky. They indulge in all kinds of "Dionysiac" hedonism, in part justified by the proximity of Delos where they believe Dionysos was worshipped and amoral debauchery took place in Ancient times. The consumption of addictive substances features prominently in Bousiou's ethnography (drug-taking was the initial focus of her research). There also seems to be a lot of sexual experimentation going on, although the author is rather discreet about that topic.

Mykoniots have a tendency to reminiscence nostalgically about their group’s past, or rather its multiple pasts, such as the hippie years before the onset of mass tourism on the island. They have a peculiar perception of time, linked to changes in the weather, changing seasons, and phases of the moon, punctuated by some Orthodox and Indian holy days. The group is mostly made up of men, some of them acting out their masculinity, others not at all. Some strong, charismatic, talented women are also part of the group. Social reproduction takes place through a "system” of discipleship, even if nothing is ever very systematic or well-planned in advance in a Mykoniot's life, as Bousiou shows. An aspiring Mykoniot has to 
live with or work for an established member of the group for an unspecified length of time before being accepted as one of them. The author estimates that there are between 300 and 500 group members gravitating around a much smaller number of core personalities.

Pola Bousiou treats us to some vivid ethnography, such as descriptions of the annual gate-crashing trip to the ancient site of Delos in September, followed by a late-night beach party; an unusual wedding ceremony; and a farewell ceremony where ashes are scattered on a Mykonos beach. Daily routines and yearly rituals of Mykoniots are set out for the reader. Bousiou has also included several life-histories of what can only appear as exceptional, eccentric individuals to the hoi polloi.

Before getting to these enthralling ethnographic accounts, however, the reader has to plough through exceedingly lengthy passages of theoretical reflection. Augé, Baudrillard, Bauman, Benjamin, Bhabha, Bourdieu, Clifford and Marcus, Derrida, Taussig: Just about everyone fashionable in the 1990s theoretical pantheon figures here. The text is scattered with the dominant anthropological buzzwords of the beginning 21st century: liminality, idiosyncracy, performance, narrative, (commodity) fetishism, self, construction, gaze, hybridity, reflexivity, aesthetics. One has to be of the same synaphi (group sharing a particular aesthetic sensibility) as the author to fully appreciate these theoretical developments. My personal conviction is that Pola Bousiou's ethnography is strong enough to stand on its own feet and would not have needed half of these references to other people's work and thought. By contrast, factual passages on Mykonos’ recent social history appear sometimes strangely disembodied - who says what and when? Some essential explanations are relegated to the endnotes of each chapter, which are all worth reading in detail.

Perhaps as an idea for further research and publication, one would like to learn more about the locals’ and tourists’ experience (or even “consumption”?) of the Mykoniots. The author's best intentions to the contrary, these two groups (native Mykonians and conventional 
tourists) are portrayed in a vague, at times almost disparaging way. This is without doubt due to the fact that some key informants perceived their temporary or permanent neighbours on Mykonos as monolithic and rather uninteresting categories of people. Locals provide the Mykoniots with lodgings, authentic food grown in some rare surviving garden plots, opportunities to revel in Orthodox festivals, and boat trips to the adjacent islands of Delos and Rhenia. While locals figure as a service-providers, tourists are mainly consumers: they buy drinks, food and objects in bars or shops run by Mykoniots and thus contribute to their livelihood. To some extent, they are also a recruitment pool for the group, producing admirers and disciples. Otherwise they rather seem to disturb, and the main challenge in summer is to live on the island while avoiding contact with plebeian or nouveaux riches tourists.

It was a conscious, but in my view regrettable choice of the author not to include any photographs, apart from a single black-and-white full-length portrait in a beach setting on the front cover.

The Nomads of Mykonos is an intellectual tour de force and a haunting read, including some touching and thought-provoking portraits of exceptional individuals. Choosing and in some ways creating such an unusual group of informants, Pola Bousiou leaves the welltrodden paths of anthropologists in Greece. For Bousiou's Mykoniots, the kin group is rather an embarrassment. Unlike Loizos’s Cypriot refugees and Lawrence’s Argolid citrus farmers, they do not aim at founding a family and amassing or preserving property that can be passed on to descendants. Some of them are part of the Greek diaspora in London, New York or India for months or years on a row, returning to their chosen homeland on special occasions only. Their outlook is cosmopolitan, and, characteristically, they befriend rather than reject Albanian immigrants living in the same island communities. 
The three books reviewed portray groups of Greek-speaking people in very different predicaments. All authors are careful to underline their informants' interaction with socially, politically or culturally dissimilar communities sharing the same space. To a varying degree and within diverging theoretical frameworks, all three are attentive to historical change. And strikingly - without wanting to nail down an elusive essential character in any way - all Greek or Cypriot people investigated happen to have two things in common: firstly, discourses replete with historical references, in which personal, local and national memories are interwoven; and secondly, a particular attachment to the soil, be it a bag with some cherished earth dug out of a refugee’s former garden and smuggled over the Cypriot Green Line, that unproductive olive grove plot in Argolida that even a debt-ridden farmer would never sell, or the barren Mykonian landscape bathed in bright, "Delian” sunlight and lashed by meltemi winds.

A final remark on editorial practices: if, as one might rightfully expect, more books on Greece will be published in the various anthropological series hosted by Berghahn Books, the publishing house might want to decide on a common policy of transliteration of Greek works and citation of Greek references. Lawrence has consistently transliterated all terms, names and book or article titles. Loizos has added several original Greek titles in his bibliography, but oddly some letters come out as question marks. In Bousiou’s bibliography, finally, printer fonts seem to change in the middle of some Greek words. The copy-editing process could surely be improved.

\section{References cited:}

Durrell, Lawrence. 1978. The Greek Islands. London: Faber \& Faber.

Loizos, Peter. 1975. The Greek Gift: Politics in a Cypriot Village. Oxford: Blackwell.

Loizos, Peter. 1981. The Heart Grown Bitter: A Chronicle of Cypriot War Refugees. Cambridge: Cambridge University Press. 